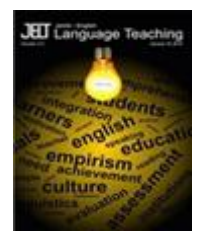

Jambi-English Language Teaching Journal

http://online-journal.unja.ac.id/index.php/jelt/index

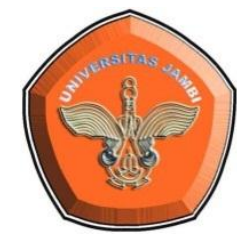

\title{
PRAGMATIC COMPETENCE AS THE ART OF LANGUAGE USE IN INTERACTION
}

\author{
Vrenti Siska \\ vrent1_Siska@yahoo.co.id \\ Lampung University
}

Received 4 December 2015

Received in revised form 15 February 2016

Accepted 17 April 2016

Published online 15 May 2016

\begin{abstract}
The ultimate goal of the research was to delineate EFL students' bilingual school interaction to find out Pragmatic aspects in term of cooperation among the participants, and politeness strategy. Since pragmatic competence holds important role in language learning instead of linguistic competence. The research subjects were English native teacher and 24 students of third grade of Tunas Mekar Indonesia Elementary School. To find out pragmatics' aspects of the interaction, the researcher analyzed teacher's and students' utterances by transcribing, coding and classifying them based on the theory. The findings show that pragmatic competence is very needed to be applied in the interaction, the teacher should be first model for their students in the classroom communicative activity. The teacher's utterances or speech acts should be understandable by the students, thus ultimate goal of communication can be shared. Pragmatics deals with some aspects which can be implemented as references to conduct manner through language use contextually and appropriately. It directs the participants to cooperate achieving communication goals through various guidance which reflect good values and politeness strategy of language use. In another word, it is the art of language use in the interaction.
\end{abstract}

Key words: Pragmatic Competence, Speech Act, Cooperative Principle, Politeness

\section{Introduction}

Creating a real life situation in English Language teaching has become a fashion in recent years. To be exact that is communicative approach. It provides a solution to overcome the problem that has existed in EFL teaching for years. The problem is, the students unable to communicate using English after receiving several years of English learning. Since communicative competence is the ultimate goal of English learning, it covers several aspects to be considered in language 
teaching, namely linguistic competence, sociolinguistic competence, discourse competence and strategic competence. (Canale: 1983). The latest aspect of Communicative Competence proposed by Bachman (1990 ) includes Pragmatic knowledge as important aspect instead of linguistic knowledge. Pragmatic knowledge has covered other aspects which stated previously, such as sociolinguistic competence, discourse competence and strategic competence.

Pragmatic Competence becomes important field to be investigated by many researchers. Since it studies the language use in the real context. It can delineate how speaker and hearer or writer and reader cooperate to reach the communication goals. Through the language use also can reflect the participants' manner and strategy in interaction. Several studies dealing with pragmatic awareness and competence have been conducted by Brock and Nagasaka (2005) delineate that pragmatic competence can be provided by the teacher in designing students' activities. Another study has been done by Frasher (2010), he concludes that the lack of pragmatic competence can create serious problems for second language speaker is that hedging. When non native speaker fail to hedge appropriately, they may be perceived as impolite, offensive, arrogant, or simply inappropriate. Moreover, Lamri (2014) finds that developing learners' communicative and pragmatic competence is essential if it is aiming at naturalistic use of language. From the previous studies can be synthesized that pragmatic competence holds important part in language learning. It is insufficient only providing students mastery linguistic competence without pragmatic competence, in which it involves some aspects which can be implemented as a guidance to be success in communication and interaction. Further, by analyzing pragmatics aspects can be delineated one's behavior in terms of cooperation and politeness in interaction.

Referring previous description, the researcher would like to observe EFL students' bilingual school whose the English teacher is a native speaker to find out Pragmatic aspects in term of cooperation among the participants, and politeness strategy used in interaction.

\section{Literature Review}

\section{Pragmatic Competence in Language Teaching}

Pragmatic competence will be a consideration for the students to be competent in a language besides other aspects. It discusses the meaning of utterances and how its function based on the context of the speaker and hearer. Canale (1983) states that pragmatic ability is included under "sociolinguistic competence", called rules of use. Other definition of pragmatic described by Leech (1983) focuses on pragmatics as interpersonal rhetoric the way the speaker and writers accomplish goals as social actors who do not just need to get things done but must attend to their interpersonal relationships with other participants at the same time. Moreover, Yule (1996:3) defines pragmatics into four definitions: 1) Pragmatics is the study of speaker's meaning; in other words, it has consequently, more to do with the analysis of what people mean by their utterances. 2) Pragmatics is the study on contextual meaning; it requires a considerations how the speakers organize what they want to say in accordance with who they're 
talking to, where, when, and under what circumstances. 3) Pragmatics is the study of how more gets communicated than it said. 4) Pragmatics is the study of the expression of relative distance. Furthermore, Crystal (1997) proposes that pragmatics is "the study of language from the point of view of users, especially of the choices they make, the constraints they encounter in using language in social interaction and the effects their use of language has no other participants in act of communication". In other words, pragmatic is defined as the study of communicative action in its sociocultural context.

From previous description, it can be highlighted that pragmatics actually happens in communication which involves speaker and hearer and it depends on the context. The language use in the class room setting can be defined as speech act. It relates to utterances produced by the teacher and students. It becomes an ability to communicate intended message, it is often not given emphasis it deserves in the teaching of a second or foreign language. It is important to have pragmatic competence instead of linguistic competence because the speaker who is lack of pragmatic competence may produce grammatically flawless that nonetheless fails to achieve its communicative aims. Therefore, the teacher's role in raising students' pragmatic competence is very needed, since it is useful to be used to maintain social relationship.

\section{Speech Act}

Dealing with pragmatics, speech acts become unit analysis of the field in form of utterances which are produced by interlocutors. Austin (1962) firstly introduced Speech Act Theory and Searle (1969) further elaborated it from the fundamental of language is used to carry out actions. Austin said that when a speaker utters a sentence, she/he may perform three types of acts : Locutionary act, Illocutionary act, and Perlocutionary act. Locutionary act is described as an act of uttering a sentence with certain sense of reference or it is equivalent to 'meaning' in the traditional sense. Illocutionary act is an act of performing the act of informing, claiming, guessing, reminding, warning, threatening, requesting and many more. Searle (1969) also says that utterances are associated with illocutionary act they intend to perform explicitly. The last is perlocutionary act, it is such as causing people to refer to the truth of statement, causing an addressee to feel requirement to do something, and so on. Through speech act analysis in communication, we can see further effect of language use which shows appropriateness and politeness.

\section{Cooperative Principle and Politeness}

Grice's Cooperative principle (CP) was the cornerstone of models that explain polite utterance. At the same time this model also recognizes that such utterance appear to violate one or more of Gricean maxims. Polite language is a form of cooperative behavior but does not see to abide by Grice's CP. In order to correct this apparent anomaly, Lakoff (1989) adopts Grice's suggestion that a politeness principle might be added to the $\mathrm{CP}$ and suggests that maxims of $\mathrm{CP}$ are subordinated to those of the Politeness Principle.

Cooperative Principle: 
"Make your own conversation contribution such as required at the stage at which it occurs, by the accepted purpose or direction of the talk exchange in which you are engaged" (Grice, 1975: 45)

$\mathrm{Su}$ bsumed under the general principle, Grice (1975: 45-46) distinguishes four categories of more specific maxims and sub maxims, enjoying, truthfulness, informativeness, relevance and clarity. He shed lighted further into:

- Quantity: Make your contribution as informative as is required (for the current purposes of the exchange. Do not make your contribution more informative that is required.

- Quality: Try to make your contribution one that is true. Specifically: (1) Do not say what you believe to be false; (2) Do not say that for which you lack of evidence.

- Relation: Be relevant.

- Manner: Be perspicuous. Specifically: (1) Be brief; (2) Be orderly; (3) Avoid ambiguity; (4) Avoid obscuring of expression.

In short, through following the maxims or rules of conversation, the participants directly cooperated each other to achieve communication goals. However, people do not always follow the $\mathrm{CP}$ in the real world. People often try not to give information which they do not want to release, they face it at risk. It is not easy for them to be sincere and violations of Grice maxims occur. Criticize on Grice theory appeared to complete his CP theory, Ladegaard (2008) analyzes conflicts with Grice position. He claims "human interaction may be irrational and illogical, and that resistance and non-cooperation may be adopted as the preferred discursive strategy, and that interactions seem to try best to be 'bad communicators'

Moreover, Lagaard (2008) considers the two types of cooperation related to Gricean theory, "social goal-sharing and linguistic goal-sharing". Grice theory does not take the social context into account, and only consider the speakerlistener interaction in an ideal context, and applies universally (regardless of social elements such as sex, power relationship, social class, and age).

The important purpose in following the rule of conversation is to maintain good social interaction among interlocutors. It also directs the speaker and hearer to share mutual knowledge to achieve communication goals. Further, the utterances produced show the degree of politeness of someone. Robin Lakoff (1989) could well be called the mother of modern politeness theory, for she was one of the first to examine it from a decidedly pragmatic perspective. She defines politeness as "[...] a system of interpersonal relations designed to facilitate interaction by minimizing the potential for conflict and confrontation inherent in all human interchange" Lakoff (1990:34). With roots in Generative Semantics (Lakoff 1989b), used politeness to point out certain weaknesses of traditional linguistic theory, and did this by connecting politeness with Grice's Cooperative Principle (CP).

Grice's theory rests on the assumption that people are intrinsically cooperative and aim to be as informative as possible in communication informatively referring to a maximally efficient information transfer. These 
assumptions are captured by the $\mathrm{CP}$ and its associated maxims of Quantity, Quality, Relation and Manner, which function as rules of linguistic behavior governing linguistic production and interpretation. When they are followed (which according to Grice is the default situation), maximally informative communication or clarity is reached.

Thus, whereas the $\mathrm{CP}$ is geared to the 'information content' of communication, the politeness rule attends to social issues. If hearers notice that speakers do not seem to be following the Gricean maxims to the fullest, they search for a plausible explanation in the politeness rule: if speakers are not maximally clear, then maybe they are trying to avoid giving of- fence. In all, three such politeness rules are envisaged: 'Don't impose' (rule 1), 'Give options' (rule 2) and 'Make A feel good, be friendly' (rule 3, 'A' being 'Alter') (Lakoff 1973:298). Although these rules are all to some extent always present in any interaction, different cultures tend to emphasize one or other of them. Thus, definitions of politeness - of how to be polite - differ inter culturally. Depending on which of the rules is most important, cultures can be said to adhere to a strategy of Distance (rule 1), Deference (rule 2), or Camaraderie (rule 3) (Lakoff 1990:35). Distance is characterized as a strategy of impersonality, Deference as hesitancy, and Camaraderie as informality.

\section{Methodology}

The qualitative content analysis was used in analyzing the findings, in which the researcher took video recording of bilingual classroom interaction. The English teacher is a native speaker who has taught for five years in the school and the class consisted of 24 students with equal number of males and females. The video recording was taken for two hours of English learning or around 90 minutes. The topic of the lesson was about "Road Safety". Then, teacher's and students' utterances were as the data sources. To find out how the participants cooperate to achieve communication goal and politeness reflected through the language use, the data were transcribed then coded. Finally, those findings were narrated and synthesized based on the previous studies and theories to draw the conclusion.

\section{Research Findings Research Setting}

The research was conducted in Tunas Mekar Indonesia (TMI) School in May 2015, it is one of bilingual schools in Bandar Lampung whose the English teacher is a native speaker. The writer assumed that communicative classroom interaction occur in TMI, since the school implements submersion bilingual program. The third grade of TMI elementary was chosen by considering that students' English ability are quite good based on their English teacher's information and scores' record. To meet the objective of the research, the researcher took a video recording to describe the findings in terms of pragmatic aspect which can be seen in the classroom interaction. The teacher and students utterances were transcribed then they were coded to be analyzed. 


\section{The Result of the Findings}

The topic of the lesson was about road safety in which the teacher tried to make students aware of the importance road safety in the real life. Most activities happened in the classroom were seemed communicative, the teacher was used to engage the students to respond any questions related to the topic. The teacher sometimes made paraphrasing to make the students understand his questions. Mostly teacher questions were in form of short answer (yes/no) in order to check students' comprehension. Teacher also used non verbal strategy in explaining certain words which were hardly to be understood by students. Drawing simple pictures on the white board or explaining by using gesture were also done by the teacher. The class atmosphere looked enjoyment and the students learned in relax condition, therefore, their activities in exploring the topic could be seen maximum by the guidance of the teacher.

Dealing with one of pragmatic aspects how the participants cooperate to achieve goal of communication, the researcher will delineate research findings by giving examples of teacher and students' utterances. It can be described that teacher's utterances or speech acts mostly in form of implicit command or request. In the opening session of the lesson, the teacher asked one of the students to lead praying in front of the class. The teacher's command was in form of indirect request or offering, such as : "Who wants to be famous?". "Does anyone want to be famous?. "Ok you'll be on movie". Those utterances were intended to ask the students to be volunteer to lead praying. The teacher used the word "famous" was caused of the presence of the researcher in the classroom. The researcher took video recording of classroom activities as data collecting technique. In the pre activity session, the teacher did interpersonal conversation to expose the students to participate in communication. He did not point directly to the students or commanding. It lessened students' anxiety or discomfort feeling to be imposed. It matched with the rules of politeness to give option and don't impose (Lakoof, 1973). Even though the teacher had authority to control the class, but he used another strategy in ordering his students to do something. Referring to examples of teacher's utterances in asking his students to lead praying, the students seemed were not confident to be volunteer. It can be seen from the student's responses of the following conversation.

$\mathrm{T}$ : You want to be famous? (talk to one of the students who seems want to be volunteer)

$\mathrm{S}: Y a$.

$\mathrm{T}:$ Ok, you want to be famous (offering the student to come in front of the class)

$\mathrm{S}$ : But not now (Seem unconfident)

$\mathrm{T}$ : Ok, because you're shy, you can choose one of your friend (ask another student to

accompany leading praying)

From the conversation between teacher and students, it can be concluded that the teacher used pragmatic strategy in ordering by using "offering "expression. It did not show that the teacher imposed his students with his authority. It reflects politeness strategy proposed by Lakoff (1977) (don't impose 
and give option). Further, the teacher knew his students' comprehension of his utterances, he tried to clarify and simplify as follow : "Who wants to be famous"...." Does anyone want to be famous?....You want to be famous?. Those repetitions were purposefully to fulfill the proper information in term of quantity and clarity. Those intended were to make the students understand with teacher's aim and also it can be used as exposures. From the psychological side also can be seen becoming the teacher concern, for example when one of the students felt shy to lead praying, the teacher offered her to choose a friend to accompany her. Finally, its strategy was success that two students lead their friends praying before starting the lesson.

Moreover, when two students lead praying, they were intended to ask their friends to be grateful to God. A Language can express intended purpose directly or indirectly. Expressive speech acts teach the students to be sincere in their daily life. It belongs to pragmatics where it learns the art of language use in interaction. The use of language would be more emphasized on social interaction among the participants. The following pray shows the sincerity expression uttered by the students, "Dear God, Thank you for today. Please, help us to improve our English. Please, help us to do our best...Amiin!". Its pray content was relevant with their learning goal, it also reflected politeness in begging to God. The word "please" has indirect purpose, it is similar to "asking" but it was soften or can be called as a mitigating in politeness strategy.

The next findings that the researcher would like to high light were about manner refers to cooperative principle done by the teacher in the main activities when checking students' tasks. Manner is one of the maxims which will be a guidance to reach interaction goal. When the students showed their tasks to their teacher and they were responded by the teacher using the following utterances : : "It's dangerous, I'm sorry" (give back student's book), "Sorry, no one get one hundred". The two utterances were not intended to show teacher's mistake toward students, thus he apologized them. It dealt with manner in cooperation, the teacher did not blame students' mistake in writing the task. It reflected how to respect someone's effort. Those forms of apologizing speech act implied that the teacher did not want to make his students disappointed of their effort in finishing the task. Its utterances also beneficial to motivate students to be better and looked more friendly. It referred to one aspects of politeness "be friendly" in the interaction. Friendliness can be shown not only between participants in the equal level, but it can be occurred between the participants who are not equally in level such as teacher and students. Its purpose is to create comfortable learning condition, especially for primary students.

\section{Conclusion and Suggestion}

Since pragmatic competence is very needed to be applied in the interaction, the teacher should be first model for their students in the classroom communicative activity. The teacher's utterances or speech acts should be understandable by the students, thus ultimate goal of communication can be shared. Pragmatics deals with some aspects which can be applied as references to conduct manner through language use contextually and appropriately. The findings 
relate to previous studies conducted by Brock and Nagasaka (2005) that pragmatic competence can be provided by the teacher in designing students' activities. It emphasizes on teacher's role in directing the students to be aware of pragmatic competence. It also similar to Frasher's study in 2010, he concludes that the lack of pragmatic competence can create serious problems for second language speaker is that hedging. It shows that pragmatic competence becomes essential in language learning recently. Moreover, the findings also match with Lamri (2014), he concludes that developing learners' communicative and pragmatic competence is essential if it is aiming at naturalistic use of language. From the previous studies can be synthesized that pragmatic competence holds important part in language learning. It deals with various aspects of language use in interaction. Language use by someone reflects who are the speakers, thus Pragmatic competence should be provided by the teacher to guide students manner in linguistic politeness through cooperation in the interaction. It is not only how to use language contextually and appropriately but deeper understanding which direct the participants to cooperate achieving communication goals through appropriate pragmatics' strategies which can reflects linguistic politeness and manner that can be called as the art of language use in the interaction.

\section{References}

Austin, J.L (1962). How to do things with words. Oxford. Clanrendon Press.

Bachman, L.F .(1990). Fundamental consideration in language testing. Oxford. Oxford University Press.

Brock, N.M and Nagasaka, K. (2005). Teaching Pragmatic Competence in the EFL Classroom?Sure You can!. TESL Reporter 38,1, 17-26. Carson Newman College, Tennessee, USA.

Canale, M. \& Swain, M. (1983). "From Communicative Competence to Communicative Language Pedagogy, "In J. Richards \& R. Schmidt (Eds). Language and Communication.London:Longman.

Crystal, D .(1997). The cambridge encyclopedia of the english language. Cambridge University Press.

Frasher, B . (2010). Pragmatic competence: the case of hedging. Emerald Group Publishing Limited.

Grice, P. (1975). Logic and Conversation. In P. Cole \& J. Morgan (eds.),Syntax and Semantics, Vol 3, 41-58 Speech Acts. New York: Academic Press,.

Geoffry,L.(1983). Principles of pragmatics. New York. Longman Linguistic Library.

Hymes, D.H .(1972). On Communicative Competence. In Pride, J.B \& Holmes. J (Eds),Sociolinguistics. Baltimore, USA:Penguin Education, Penguin books Ltd.

Ladegaard, H.J. (2008). Pragmatic Cooperation revisited: Resistance and noncooperation as a discursive Strategy in asymetrical discourse. Journal of Pragmatics in press.

Lakoff, R.T.(1973). The Logic of Politeness; or, minding your p's and q's. the Ninth Regional Meeting of the Chicago Linguistics Society. Chicago: Chicago Linguistic Society. 
Lakoff, R.T. (1977). What you can do with words: Politeness, pragmatics and performative. In Proceedings of the Texas Conference on Performative, Presuppositions and Implicatures, ed. R. Rogers, R. Wall \& J. Murphy. Arlington, Va: Center for Applied Linguistics.

Leech, G. (1983). Principles of pragmatics. New York. Longman Linguistic Library.

Lamri, S. (2014). Developing pragmatic competence in the efl context: opportunities and challenges. Biskra University.

Searle, J.R. (1969). Speech acts. Cambridge: Cambridge University Press.

Beh, Y. (1997). Current research in Southeast Asia. RELCJournal, 28(1), 175-179.

Education First. (2013). EF: English proficiency index. Retrieved from www.ef.com./epi.

Fraenkel, J. R., \& Norman R, W. (1990). How to design and evaluate research in education. New York, NY: McGraw Hill, Inc.

Kusmaryati, S. (2009).Improving speaking achievement through classroom discussion. Bahasa danSeni. 34(1), 234-256.

Lee, C., Chao, L., \& Chen. (2011). The influence of interest in learning and learning hours on learning outcomes of vocational college students in Taiwan; Using a teacher's' instructional attitude as the moderator.Global Journal of Engineering Education, 2(2), 16-20. 